\title{
Bæredygtighed er det næste store skridt i velfærdssamfundets udvikling
}

\author{
Af Steen Hildebrandt *)
}

\begin{abstract}
Resumé
Den lille bog fra 1945, Fremtidens Danmark, var Socialdemokratiets partiprogram til det første folketingsvalg efter Anden verdenskrig, og var i virkeligheden en drejebog for udviklingen af det velfærdssamfund, der blev skabt i Danmark i årene efter verdenskrigen. Det var en enestående samfundstænkning, der her blev udfoldet. Denne tænkning bidrog markant til udviklingen af det samfund, som Danmark er blevet - og er blevet berømt for. Men vi må erkende, at dette velfærdssamfund også er blevet et samfund, der på mange måder er et ikke-bæredygtigt samfund. Bæredygtighed har ikke været en eksplicit bestræbelse i det vækst-, produktions- og produktivitetsparadigme, der har karakteriseret årene efter Anden verdenskrig. Nu er den store udfordring at formulere en drejebog for udviklingen af et bæredygtigt velfærdssamfund. Hvordan ser et bæredygtigt velfærdssamfund, en bæredygtig kommune - og en bæredygtig verden ud? Hvordan ser fremtidens bæredygtige Danmark ud? Vi ved det ikke, men verdensmålene kan hjælpe os med at finde svarene på disse spørgsmål. Verdensmålene er en terminologi og en ramme for beskrivelsen og realiseringen af et nyt bæredygtigt samfund.
\end{abstract}

\section{Emneord}

Bæredygtighed; velværdssamfund; lederskab; det bæredygtige velfærdssamfund; FN's 17 bæredygtighedsmål

*) Steen Hildebrandt er Ph.d., forfatter og professor emeritus ved Aarhus Universitet og adjungeret professor ved Copenhagen Business School. 


\section{A. Indledning}

\section{Baggrund}

I den politiske debat taler vi fortsat om blå og rød blok, om højre- og venstrefløj, om liberalisme og socialisme. Men vi mærker og hører, at det er kategorier, der er skrøbelige, om ikke i frit fald. Vi udtaler ikke ordene så selvsikkert, klart og højt, som før, for vi véd godt, at de ikke holder længere. De er ved at krakelere. Virkeligheden er løbet fra disse kategorier. De geologiske, økonomiske, kulturelle, geopolitiske, sociologiske og psykologiske dogmer, som disse kategorier og Universitet var baseret på, vakler. De vakler og krakelerer, fordi flere og flere menneskers intuition og erfaringer samt mere og mere ny forskning problematiserer, modsiger, demonterer og stiller stærkt kritiske spørgsmål til de antagelser, forudsætninger og konklusioner, som disse dogmer og politiske ismer baseres på. Der er behov for at skabe bevægelse i et stivnet dansk politisk debatklima. Der er behov for nye kategorier og betragtningsmåder.

I sidste halvdel af 1900-tallet blev det gamle danske håndværks- og landbrugssamfund transformeret til et velfærdssamfund, og i de sidste årtier af århundredet blev velfærdssamfundet videreudviklet til at blive en konkurrencestat. I en bog med titlen Konkurrencestaten Danmark rejses spørgsmålet: Skal hverdagen ligne en slutspurt? For sådan ser det faktisk ud på mange områder. Konkurrencestaten udstillede svaghederne i den ideologi om konkurrence, virksomhedsledelse og økonomisk vækst, som den politiske og økonomiske tænkning i velfærds- og konkurrencestaten var baseret på. De sidste to hundrede års industrielle revolutioner og deres værdier om uhæmmet konkurrence og ressourceforbrug, den teknologiske og befolkningsmæssige udvikling, den såkaldt frie prisdannelse og den private ejendomsrets flere og flere bizarre og til dels uforudsete konsekvenser, har efterhånden akkumuleret så mange negative effekter og sideeffekter, at de politiske dogmer og programmer falder fra hinanden.

\section{Kriser}

Vi er havnet i en økologisk, social, kulturel og spirituel krise. På et overordnet plan ser den uundgåelige og nødvendige vej videre frem ud til at handle om bæredygtighed. Der er, som det er blevet udtrykt, ingen vej uden om bæredygtighed. Men hvordan disse veje frem mod mere og mere bæredygtighed kan eller skal se ud, har vi lige nu kun begrænset viden om, og derfor er der plads til og behov for mange meninger om og holdninger til disse store spørgsmål. Dybest set handler det om en række grundspørgsmål, som vedkommer os alle, og som bl.a. handler om vort praktiserede menneske-, kultur- og natursyn. Vi skal tage disse grundlæggende spørgsmål, temaer og problemer alvorligt og drøfte dem med det formål at være i stand til at svare på de udfordringer og ønsker, som kommer til os fra fremtiden, og som de nævnte kriser er vidnesbyrd om.

Sat på spidsen er vi måske i en situation, hvor det både er rigtigt, at verden er ved at blive kørt i sænk af uansvarlige, egoistiske, hensynsløse og grådige kapitalister, og samtidig er verden ved at 
blive reddet af ansvarlige, solidariske og engagerede både unge og ældre mennesker. Den ene statistik efter den anden (fx FN-rapporten, The Future is now. Global Sustainable Development Report 2019) viser, at udviklingen i verden på en række dimensioner går i forkerte retninger. Uligheden, affaldsmængderne, reduktionen af biodiversiteten, udledningen af forskellige giftstoffer, mængden af den ikke-bæredygtige produktion, byggeri og transport vokser.

Men der kan også peges på en række andre fænomener, lyspunkter og udviklingstræk, hvor både unge mennesker og de fæle kapitalister bidrager til en stadig mere bæredygtig udvikling. Bestyrelsesformand Jim Hagemann Snabe udtaler fx til Berlingske (den 18. januar 2020): "Europa skal være rollemodel for ansvarlig kapitalisme". Og den ansete amerikanske gruppe af erhvervslevere, The Business Roundtable, placerer ifølge Financial Times (august 2019) for første gang aktionærerne som blot én ud af fem sideordnede stakeholders på linje med kunderne, de ansatte, leverandørerne og det omgivende samfund.

\section{B. Fremtidens Danmark - et partiprogram}

Vi vender nu tilbage til bogen og partiprogrammet Fremtidens Danmark. Tilbage i vinteren 1944 sad den dengang 30-årige kontorchef i Arbejderbevægelsens Erhvervsråd, cand.polit. Jens Otto Krag i en lejlighed i København og skrev bogen og partiprogrammet: "Fremtidens Danmark. Socialdemokratiets politik". Han var i november måned samme år blevet sekretær for Socialiseringsudvalget; et udvalg, oprindeligt nedsat af Socialdemokratiet efter Første verdenskrig, og nu genetableret med den opgave at formulere partiets arbejdsprogram for efterkrigstiden og det folketingsvalg, der måtte komme, når Anden verdenskrig snart ville slutte. Udvalgets formand var fhv. minister Alsing Andersen, og det bestod af bl.a. Vilhelm Buhl, Hans Hedtoft, H. C. Hansen (alle tidligere eller kommende statsministre) og mange flere. I alt 34 medlemmer deltog, da udvalget mødtes første gang den 24. november 1944 i Karl Marx-salen i Folkets Hus i København. Man kan bl.a. læse om dette udvalg og dets arbejde i Bo Lidegaards fremragende to-binds værk om J. O. Krag (1914-1978).

Fremtidens Danmark var allerede dengang, og er helt klart også i et tilbageblik, en meget interessant og visionær publikation, der er skrevet på et tidspunkt, hvor der var krig i verden, og hvor Danmark var besat; der var megen fattigdom og stor social ulighed. På trods af det er det en bog, ikke bare om et andet, men om et helt andet samfund - og en anden verden. Ordet velfærdsstat forekommer ikke i bogen, men bogen var i virkeligheden en beskrivelse af det, der blev til velfærdsstaten, en stat og et samfund, som ingen nogen sinde havde set. Og det var i virkeligheden også en indledende beskrivelse af den senere så velkendte konkurrencestat. 
Det var en bog og et arbejdsprogram om produktion, produktivitet, fuld beskæftigelse og konkurrence. En bog og en programerklæring om vækst. Det kunne ikke gå hurtigt nok, og den vækst, som man talte meget om, skulle opnås næsten for enhver pris. Der skulle sikres mere social, økonomisk og kulturel lighed og retfærdighed. Der skulle udvikles politisk og økonomisk demokrati. Erhvervslivets betydning for opnåelsen af mere økonomisk og materiel vækst og velfærd for de store befolkningsgrupper blev understreget. Der skulle sikres en mere retfærdig fordeling af samfundets ressourcer og goder, og grundlaget skulle skabes for en mere demokratisk og reel adgang til alle slags uddannelser for mange flere mennesker. Kort sagt: Det handlede om udviklingen af det velfærdssamfund, som J. O. Krag var optaget af, og som han - måske mere end nogen anden enkeltperson - kom til at spille en hovedrolle i udviklingen af. Men der var ingen, der talte om bæredygtighed. Det var der ingen grund til. Alt var muligt. Der var ressourcer nok. Det var på alle måder en anden verden - dengang i 1945 - og derfor var der ingen grund til at tale om bæredygtighed, ressourcer, miljøbeskyttelse etc.

\section{Visionær fremtidstænkning - en drejebog}

Det er ikke svært at forestille sig alle disse fremtidsforestillinger i dag, men man skal erindre, at dette blev tænkt og skrevet på et tidspunkt, hvor alt i verden - og i Danmark - var fuldstændig anderledes. Det var i sandhed dristig og visionær fremtidstænkning af en helt særlig karat. Man kan læse Fremtidens Danmark på nettet; da bogen og arbejdsprogrammet i sin tid udkom, var det en lille tynd bog med blåt omslag og røde bogstaver. Programmet blev vedtaget på Socialdemokratiets kongres i august måned 1945 og fremlagt som en del af Socialdemokratiets program ved det første folketingsvalg efter krigen, et valg, der blev afholdt den 30. oktober 1945. Dette første valg efter krigen førte til, at partiet Venstre dannede regering med Knud Kristensen som statsminister.

Fremtidens Danmark er i virkeligheden en slags drejebog for den samfundsudvikling, der fandt sted i Danmark (og i Skandinavien) i resten af det 20. århundrede. En fantastisk og dristig fremtidstænkning. Det var en kraftpræstation at tænke denne mulige nye verden frem. Og en ny verden var det; det var et varsel om mulige helt nye tider. Og allerede i 1947 fik Socialdemokratiet mulighed for at danne den første socialdemokratiske regering efter Anden Verdenskrig. Hans Hedtoft blev statsminister, og J. O. Krag blev Minister for handel, industri og søfart. Han var den yngste minister i regeringen. Og så begyndte realiseringen af nogle af visionerne i Fremtidens Danmark.

\section{Marshall-hjælpen}

På det tidspunkt, i 1947, havde den amerikanske udenrigsminister George Marshall netop holdt en berømt tale, hvori han annoncerede USA's økonomiske genopbygningshjælp til de europæiske lande, det, der senere skulle kendes som Marshall-hjælpen og som Marshall-penge. J. O. Krag var som 
minister med til at administrere disse penge i Danmark. Pengene skulle bruges til de oven for nævnte tre ord: produktion, produktivitet og konkurrence. Ud af de i alt ca. 13 milliarder dollars, som USA bidrog med til Europas genopbygning i årene efter krigen, fik Danmark 385 millioner dollars. Det var som et led i hele dette økonomiske arrangement, at OEEC, Organisation for European Economic Co-operation, blev dannet i 1948 - og senere, i 1961, omdannet til OECD, Organisation for Economic Co-operation and Development, en organisation, der i perioden 1960-1969 havde fhv. finansminister og professor Thorkild Kristensen som generalsekretær.

\section{Handelsministeriets Produktivitetsudvalg}

En central del af de politiske initiativer, der skulle bidrage til udmøntningen af noget af tænkningen i Fremtidens Danmarks i praksis, blev det såkaldte Handelsministeriets Produktivitetsudvalg, der blev nedsat af J. O. Krag i 1949. Det bestod af embedsmænd, forskere og repræsentanter fra fagbevægelsen og erhvervslivet. Det skulle komme til at symbolisere meget af den politiske, ledelsesmæssige og erhvervsmæssige tænkning og praksis, der kom til at præge mange af de efterfølgende års indsatser i Danmark. Perioden fra 1945 og frem til 1970'erne er da også efterfølgende blevet kaldt "De 30 gloriøse år”. Man har ligefrem talt om en produktivitetsbevægelse. Ledelse og produktivitet var nøgleord. Det var ikke business (produktion) as usual. Man skulle netop ikke bare fortsætte med at arbejde og producere, som man havde gjort det i årene op til Anden Verdenskrig. Man skulle have meget mere ud af ressourcerne - og det lykkedes i den grad. Øget produktivitet var nøgleordet. Og hovedressourcen var mennesker. Det var mennesker, der skulle være stadig mere produktive. Rationalisering, arbejds-, metode- og tidsstudier, Time management mm. var nøgleord.

Konkurrencestaten blev vel i virkeligheden også grundlagt her. Fremtidens Danmark og Produktivitetsudvalget var konkurrencestatsfænomener. Set i det lys er det interessant at studere, hvad produktivitetsudvalget havde som opgave, og hvordan man løste opgaven. Om det kan man bl.a. læse i en bog fra Gyldendal, der i 2013 blev udgivet som én ud af 12 bøger i serien: Den danske ledelseskanon, og som jeg var med til at redigere. Bogen om Handelsministeriets Produktivitetsudvalg blev faktisk til på mit forslag, fordi jeg syntes og synes, at det var et meget vigtigt og interessant ledelsesinitiativ, som J. O. Krag var en central del af. Retfærdigvis skal det siges, at initiativet blev til på forslag (eller krav) fra den amerikanske regering, men udmøntningen var dansk og meget succesfuldt gennemført. Bogen hedder: "Produktivitetsudvalget. Ledelse som vækstmotor".

Udvalget havde den opfattelse, at nogle afgørende faktorer for at løfte dansk produktivitet var: Udbredelse af ny teknik, kendskab til rationel virksomhedsledelse, lederuddannelse, medarbejderuddannelse, tilgang af råvarer og materialer samt kollektive lønaftaler. Produktivitetsudvalget skulle bl.a. gennemføre kurser og studierejser til USA. Det blev til 256 rejser 
for i alt 1191 deltagere. Der skulle skabes velfærd. Vækst i produktionen var nøglen til velstand, velfærd, udvikling, mere uddannelse, pensioner, ferier, sundhed etc. Og vi fik det hele - og mere til. Det danske velfærdssamfund udviklede sig med hastigheder og på måder, som nok ikke engang $\mathrm{J}$. O. Krag havde haft fantasi til at forestille sig i de første efterkrigsår. Men det skete. Og det var fantastisk.

\section{1957 - et nøgleår for velfærdsstatens udvikling}

Tidligere overvismand, professor emeritus Niels Kærgaard skrev en interessant kronik (Kristeligt Dagblad, den 23. oktober 2019) om denne udvikling i Danmark. Kronikken havde overskriften: "1957 var nøgleåret i velfærdsstatens historie”. I kronikken causerer Niels Kjærgaard over den politiske udvikling i Danmark i efterkrigsårene, herunder specielt over regeringsdannelsen i 1957, der førte til dannelsen af den berømte Trekantregering med H. C. Hansen som statsminister (1957-1960). Niels Kærgaards pointe er, at med denne regerings dannelse var vejen banet for de efterfølgende mange års udvikling af det velfærdssamfund, som Socialiseringsudvalget i Fremtidens Danmark havde tegnet de første og meget klare konturer af. Det er klart, at de første skridt, som antydet, allerede var taget i de foregående år, men med Trekantregeringen bliver linjen mere klar og manifest.

Meget var Fremtidens Danmark og Trekantregeringen, som J. O. Krag også var minister i (minister for udenrigsøkonomi og senere udenrigsminister), optaget af, men ikke af bæredygtighed. Tvært imod, kan man næsten sige. Man var optaget af produktion og produktivitet - næsten med overskriften: Koste hvad det i øvrigt koste ville. Marshall-midlerne strømmede til Europa i disse år, og de skulle bruges. Der skulle rationaliseres, standardiseres, effektiviseres, mekaniseres og automatiseres. Og det blev der. I datidens telefonbøger fandtes der et begreb, der hed Rationaliseringsekspert. Det var ingeniører og andre, der arbejdede med at skabe mere effektive produktionsprocesser i alle slags virksomheder. Man var optaget af virksomheders effektive drift. Effektiv ledelse. Den effektive organisation. Jo mere, desto bedre. Jo hurtigere, desto bedre. Produktivitet. Produktion. Konkurrenceevne. Vækst. Velstand. Linjen var klar. De mange studierejser og kurser virkede.

Men! Og i et efterrationaliseringens tilbageblik er der et stort Men. Det var en ikke-bæredygtig udvikling, man satte i gang og praktiserede. Vi så det ikke så klart undervejs, men det var ikke et bæredygtigt samfund, der blev udviklet i disse år. Begrebet bæredygtighed indgik ikke i Fremtidens Danmarks - og ej heller i den tids - begrebsverden. Grundtanken her var en ganske anden, nemlig: Der er ressourcer nok. Det handler om at udnytte dem - til folkets bedste. På demokratisk måde. Det var ikke klodens ressourcer og bæredygtighed, der var problemet eller udfordringen. Man tænkte i virkeligheden, og af letforståelige grunde, meget snævert. Naturen var der; ressourcerne var der; der var luft og vand, olie og kul i rigelige mængder; så rigelige mængder var der, at luft og vand i mange årtier blev brugt i de økonomiske lærebøger som eksempler på frie goder, dvs. goder, 
som man ikke behøvede at økonomisere med, for der var rigelige mængder af dem - de behøvede ikke nogen pris. Man kunne bare bruge løs. Og det gjorde man. Denne bruge-løs- og smide-væktænkning er fortsat den dominerende. Vi omgås naturens ressourcer, som om der er ubegrænsede mængder af dem; vi skænder naturen i et omfang og på måder, som man ikke skulle tro mulig. Det gør vi fortsat, men vi taler dog nu om bæredygtighed. Vi taler fortsat mere, end vi handler, og det er forhåbentlig og sandsynligvis begyndelsen til mere handling. En tendens, der fik den tidligere konservative udenrigsminister Per Stig Møller til i en kronik (Berlingske, den 14. august 2019) at skrive: "Lad os gøre op med kapitalistisk grådighed og hensynsløs effektivisering”. Nogle måneder senere fortsatte han: "De borgerlige har svigtet kapitalismekritikken" (Berlingske, den 22. februar 2020).

\section{Produktivitetskommissionen}

Så sent som i 2012, hvor den daværende Produktivitetskommission blev nedsat og begyndte at udsende sine analyser og anbefalinger, var det ikke bæredygtighed, men gammeldags produktion og produktivitet, man fortsat var optaget af. I kommissoriet hed det bl.a.: "Hvis den hidtidige svage produktivitetsudvikling fortsætter, er der betydelig risiko for, at Danmark taber yderligere terræn i forhold til andre velstående lande og derfor får svært ved at fastholde en privat og offentlig velfærd af internationalt høj kvalitet." Man var i den SR-regering og i kommissionen optaget af et simpelt gammeldags økonomisk vækst-væddeløb. Ikke af bæredygtighed. Jeg havde nær sagt: Man var overhovedet ikke optaget af bæredygtighed. Jeg blev af kommissionen inviteret til at skrive en artikel, der blev offentliggjort på kommissionens hjemmeside. Jeg gav min artikel overskriften: Bæredygtig produktivitet. Kommissionen fastholdt hele vejen igennem et traditionelt og veldokumenteret produktivitetsbegreb, som vi nu bliver nødt til at drøfte på ny - i lyset af den viden, som vi også dengang havde om nødvendigheden af en omstilling til mere bæredygtig produktion. I dag er man i produktionsvirksomheder overalt i verden optaget af, hvordan man kan arbejde stedse mere bæredygtigt. Bæredygtig produktivitet og produktion. Og det sker. Bæredygtigt forbrug og produktion er en del af verdensmålene.

Fra 1957 og til nu er der sket en næsten ufattelig udvikling i Danmark - og i verden. Den teknologiske og demografiske udvikling er eksploderet. Produktion og produktivitet ligeså. I Danmark og i verden. På 60 år er verden blevet en anden. Verden er i dag i en fuldstændig ny situation. På den positive side: Hovedtemaet er ikke bare velfærd og velstand, men bæredygtig velfærd og velstand. Udfordringen er ikke vækst, men bæredygtig vækst. Udfordringen er ikke produktion og produktivitet, men bæredygtig produktion og produktivitet. På den negative side: Nationalisme og isolationisme: Nye alvorlige risikobilleder melder sig med stor styrke, og verden er på mange måder og områder på en meget farlig kurs. Verden er skrøbelig og sårbar, hvilket alle blev mindet om, da Corona-krisen ramte det ene land og den ene verdensdel efter den anden i 2020. 


\section{Sidevirkninger}

I et tilbageblik: Den industrielle udvikling gik for hurtigt. Vi var ikke tilstrækkelig opmærksomme på den række af utilsigtede og derfor også længe upåagtede virkninger og sidevirkninger af vor travlhed og målbevidsthed, for ikke at sige af vor grådighed. Jeg kritiserer ikke de beslutninger og det verdenssyn, der lå bag disse beslutninger. Jeg konstaterer, at det er nye tider. Og jeg tillader mig at påstå - i overensstemmelse med mange andre både almindelige borgere, forskere, politikere, kunstnere og andre: Det haster med at få et nyt verdenssyn gjort til virkelighed. Vi ved det. Vi ved, at udfordringen er bæredygtighed, og FN's 17 verdensmål, bæredygtighedsmålene, peger på klare indsatsområder. Men hvad gør staterne? Hvad gør vi forbrugere og borgere?

Noget af det, der er sket i de mellemliggende 60 år, er: En ny bevidsthed er vokset frem, nye indsigter er blevet udviklet. Noget nyt var allerede tydeligt i 1972, hvor rapporten Grænser for vækst gjorde opmærksom på, at der er grænser for vækst, grænser for produktion, grænser for vore udfoldelser og ambitioner. Også bogen, Oprør fra midten med forfatterne Villy Sørensen, Niels I. Meyer og K. Helveg Petersen fra 1978 og Brundtland-rapporten, Vor fælles fremtid, fra 1987 advarede. Gjorde klart opmærksom på nogle af disse spørgsmål og temaer. Og, ja, retfærdigvis skal det også erindres, at J. O. Krag i sin tredje regering, i 1971 etablerede verdens første Ministerium for offentlige arbejder og forureningsbekæmpelse med Jens Kampmann som minister. Hvilket igen var et udtryk for J. O. Krags forudseenhed og store politiske evner og lederskab.

\section{Den nye store udfordring - og mulighed: Bæredygtighed}

Men alligevel: Vi lyttede ikke eller vi lyttede ikke grundigt nok dengang. Nu véd vi, at den næste store udfordring i udviklingen af det danske velfærdssamfund ikke er vækst og produktion, men bæredygtighed. Det er fristende at spørge - med henvisning til Niels Kærgaards overskrift: Vil vi omkring 2050 sige, at 2019, hvor Danmark - ligesom i 1957 - også fik en ny regering - og en ny klimalov, var nøgleåret i det bæredygtige velfærdssamfunds historie? Vil 2019 være året, hvor bevidstheden om bæredygtighed for alvor ændredes og fandt vej ind i alle sprækker og blev den nye dagsorden eller i hvert fald et vigtigt element i flere og flere nye dagsordener?

Vi har lov at fantasere og stille spørgsmål, og min antagelse og mit håb er, at det vil ske. 2019 - og årene heromkring - er ved at blive år, hvor bæredygtighed, bl.a. stærkt påvirket af FN's 17 verdensmål, Brundtland-tænkningen og meget andet - bliver det store og overordnede tema og den nye dagsorden. Og derfor er det også årene, hvor velfærdssamfundet videreudvikles, men i nye retninger. Eller for at være mere præcis: Velfærdssamfundet skal transformeres og nytænkes. Vi skal udvikle et nyt slags velfærdssamfund. Et bæredygtig velfærdssamfund. Og endnu engang kan Danmark vise vej - eller være med til at vise vej. 


\section{Hvilke grænser for vækst}

Det kan godt undre, at vore økonomiske modeller og teorier stort set uden undtagelser er opbygget ud fra antagelser om, at vi mennesker bare kan bruge løs af hvad som helst - det er kun et spørgsmål om at fastsætte de rigtige priser. Og hvis vi skader eller forurener naturen, så hylder vi i yderste tilfælde et princip om, at forureneren betaler. Som om man kan betale sig fra enhver skadelig påvirkning og handling? Økonomer har utvivlsomt haft en stor betydning både for samfundets og for virksomhedernes udvikling. Ingen tvivl om det, men måske har økonomer fået en alt for stor betydning for mange af de overvejelser og beslutninger, der træffes. "Tag magten tilbage fra økonomerne", sagde økonomiprofessor Katarina Juselius i Politiken, den 25. august 2019. Vi taler sjældent om, at forureneren ikke må forurene, eller at den, der bruger ressourcer, ikke må forbruge, men skal cirkulere eller recirkulere ressourcerne. Det taler vi ikke om, det kræver vi ikke. Vi lader, som om der er nok af alt. Realiteten er en anden. Vi skal stille krav, og vi skal gennem incitamenter, dvs. skatter, afgifter mm fremme bæredygtig adfærd og hæmme ikke-bæredygtig adfærd.

\section{Doughnut-økonomi}

Det er også sådanne spørgsmål, den engelske økonom Kate Raworth taler om i bogen, Doughnut økonomi. Syv principper for en fremtidig økonomi. Det er en meget lovende og vigtig modeltænkning og dagsorden, som Kate Raworth har formuleret. Formentlig noget af det mest lovende, der sker inden for det økonomiske felt i disse år. Noget vigtigt er antagelsen om, at vi ikke kan nøjes med at arbejde med begrebet: grænser for vækst; vi må i stedet interessere os for og spørge: Hvilke grænser for vækst skal vi respektere og dernæst forsøge at få disse grænser præciseret, således at man kan arbejde konkret med dem i praktisk politik og ledelse. Det er de samme tanker, der ligger bag de 8 såkaldte planetariske grænser, der er udviklet på Stockholm Resilience Center.

I Danmark er bæredygtighed også ved at være et centralt begreb samtidig med, at velfærdssamfundet fortsat er ét af de mest centrale politiske begreber. Stort set alle politikere taler om velfærdssamfundet. Det skal bevares. Sandheden er nok: Det kan ikke bevares i dets nuværende udformning. Vi må som nævnt erkende: Det danske velfærdssamfund er på mange måder og områder ikke-bæredygtigt - og derfor skal det nødvendigvis ændres, nytænkes. Ja, mere end ændres: Det skal transformeres. Det er det begreb, der bruges i FN-resolutionen om de 17 verdensmål: Transforming our world. Og dette ord skal nok også bruges om den udvikling, der skal ske med det danske velfærdssamfund.

\section{E. Globalisering}

Dengang - da Fremtidens Danmark blev skrevet og var Socialdemokratiets politiske program ved det første Folketingsvalg efter krigen - kendte og benyttede man, som tidligere nævnt, ikke ordet 
bæredygtighed; og der var et andet ord, som man heller ikke brugte, for det fandtes ikke, nemlig ordet globalisering. Verden var - på utallige måder og områder - en anden dengang. Man talte selvfølgelig om andre lande, primært som lande, man eksporterede til og importerede fra. Og, ja, FN var lige blevet etableret, og fra 1949 eksisterede NATO, og senere kom der frihandelsaftaler, økonomiske fællesskaber og organisationer, fx OECD, EU mm. Men landene var primært nationalstater. I dag er verden blevet mindre og meget mere sammenhængende.

Det giver ingen mening i dag at tale om Danmark som en isoleret størrelse, der skal løse sine egne problemer. Og heller ikke om EU som en isoleret og selvstændig enhed. De problemer og udfordringer, som vi nu er optaget af, ressourcer, klima, bæredygtighed, fattigdom, sikkerhed, migration, sundhed mm, er alle globale problemer og udfordringer. Danmark kan ikke løse sine klima-, ressource- og affaldsproblemer, og så lade de andre lande klare deres egne problemer. Det lader sig ikke gøre; det giver ingen mening, og det hænger bl.a. sammen med én af de helt store forskelle på dengang og nu: Dengang var menneskeheden endnu ikke stødt ind i den række grænser, der viser sig, når vi betragter planeten jorden som den relevante og begrænsende enhed og helhed. Vi er nu, som menneskehed, stødt ind i grænserne for, hvilke og hvor mange ressourcer, der er på planeten jorden, stødt ind i grænserne for, hvilke mængder af gasser, plast, kvælstof mm., der er plads til i atmosfæren og biosfæren. Det skyldes bl.a. og ikke mindst, og der i dag er mere end fem milliarder flere mennesker på jorden, end dengang - i 1945. Og disse i alt knap 8 milliarder mennesker har adgang til og benytter nu teknologier af en fuldstændig anden karakter og styrke end dengang, hvilket bl.a. indebærer helt andre former for påvirkninger af planeten jorden.

\section{Helhedssyn og helhedsansvar}

Derfor bruger vi nu jævnligt ordet Global: Globale fænomener, globale problemer, globale kriser etc., men undertiden er ordet forbundet med den tænkning, at når noget er et globalt anliggende, så er det ikke også et lokalt anliggende. Opfattelsen er så, at det er andre, der må tage sig af det pågældende globale problem eller anliggende. Hvem og hvor disse andre er, fortoner sig ofte i det uvisse, for realiteten er, at der ofte ikke er andre - end os selv - og alle de andre. Ethvert problem, der er globalt, er også lokalt. Det globale er lokalt. Hvis noget er globalt, kommer det netop alle ved.

Når talen fx er om FN's 17 bæredygtigheds- eller verdensmål, er ræsonnementet ofte, at det må de store, FN, EU eller USA og Kina tage sig af. Det kommer ikke den enkelte borger, det lille land eller den enkelte virksomhed ved. Man må ikke tale om det individuelle eller om det personlige ansvar i den sammenhæng, for det er at påføre mennesker en skyld eller en skam, som mennesker ikke kan bære eller fortjener. Sådan siger vi ofte, men denne tænkning er kun rigtig, når det handler om børn, for børn er selvfølgelig uden skyld og ansvar. Vi voksne har naturligvis altid et medansvar - for både delen og helheden. 
Vi har så travlt med at minde hinanden om, hvor små procentsatser det ene og det andet betyder. For når noget betyder lidt procentmæssigt, er det ikke så vigtigt. Og når det ikke er vigtigt, er det næsten uden betydning, hvad jeg og vi gør. Danmark betyder kun en lille smule, når det fx handler om fx CO2-udslip i verden, og derfor er det uden betydning i den store sammenhæng, hvad Danmark gør. Rækken af isolerede facts, der er revet ud af alle sammenhænge, og forkerte konklusioner truffet på denne baggrund er uendelig lang. Og den er farlig. Vi skal passe på! Hvis alle ræsonnerer som lige anført, sker der jo intet i verden.

\section{F. Et problem, der er globalt, er også lokalt.}

For hvad er det, vi konkluderer? Vi konkluderer, at det kun er nogle få store lande eller nogle få store brancher, der skal agere. Alle vi andre kan gøre, som vi plejer. Det er uden betydning, hvad vi gør. Og det er jo lige netop en selvindlysende forkert konklusion. Det behøver ingen forklaring eller argumentation, at jeg som enkeltindivid er af betydning, for min familie, for min arbejdsplads, for Danmark og for verden. Selvfølgelig er jeg det. Og det er alle. Vores adfærd, vore ord, sætninger, holdninger, handlinger osv. Alt er af betydning for helheden, og helheden er kommunen, landet, verden. Ét individ; ét hundrede individer; én million individer.

Hvis vi ikke passer på her, så går det galt. For så melder vi os alle lidt efter lidt ud af helheden. Vi sætter fokus på, hvad man kunne kalde simpel rationalisering, og med den konsekvens, at helheden går tabt, helheden forsvinder, i værste fald ud i den blå luft, i bedste fald ud i periferien. Den simple rationalisering går jo nemlig ud på, at vi fokuserer på og optimerer for den enkelte isolerede del for sig. Når det går vidt, ser vi på og tager hensyn til de overfladiske og uomgængelige sammenhænge, men alle de andre, underliggende og mere subtile sammenhænge, strømme, relationer etc. skærer vi over og lader ude af betragtning. Det fører til enorme mængder af, hvad vi normalt kalder suboptimering. Vi ser på og optimerer hvert delområde for sig. Og dermed forsvinder helhedssynet og helhedshensynet. Vi ser og praktiserer det overalt.

Vi skal tænke og handle i helheder, og gør vi det, indser vi straks, at jeg, Danmark, etc. er af betydning og skal tænke sig selv ind i de store helheder. Det er aldrig ligegyldigt, hvad Danmark, Varde kommune, Randersgades Skole, den enkelte virksomhed eller jeg gør - uanset, hvor lille en procentdel, vi eller jeg udgør i én eller anden konkret større sammenhæng. Jeg er af betydning for helheden; helheden er af betydning for mig. Alle problemer er både globale og lokale. Heri ligger selvfølgelig også, at der i almindelighed ikke er simple løsninger. Sammenhængene, relationerne og de gensidige afhængigheder fører kompleksitet med sig. Derfor bliver tværfaglige og tværorganisatoriske forståelser, tilgange, partnerskaber og samarbejde en del af den bæredygtige tænkning. 


\section{E. Afslutning}

Danmark hører til blandt de rigeste lande i verden. Danmark har ressourcer og evner til at gennemføre en bæredygtig omstilling i Danmark og til at være en ledestjerne for andre lande. En avisoverskrift hed: "Alle andre mennesker i verden og i historien ville dø for at have vores problemer. Det er på en måde en hån mod dem, at vi ikke er glade”. Dette er vores udfordring og opgave. Både problemerne og løsningerne er på samme tid globale og lokale, og det skal ikke få os til at give op eller træde tilbage - bare fordi Danmark er et lille land. Som altid må den stærkeste gå foran, være den generøse, og være den, der skal yde mest. Det er Danmarks situation. Danmark gjorde det i efterkrigsårene, gjorde det umulige, udviklede en vision om et velfærdssamfund - og gjorde visionen til virkelighed. Nu er udfordringen at tegne endnu en - umulig - vision, nemlig en vision om et bæredygtigt velfærdssamfund. Og gøre denne vision til virkelighed. Det er en umulig opgave, men den er mulig, og Danmark skal gribe den.

Verdensmålene skal inddrages mere eksplicit i denne debat og proces; der er i Danmark ved at være skabt et billede af, at det hele handler om klimaet. Det er ikke sandt. Klimaet er en meget vigtig faktor; der skal arbejdes intenst og målrettet med klimaet. Og samtidig er der en række andre - og med klimaet sammenhængende faktorer, som også skal have opmærksomhed og indsats. Det handler fx om biodiversitet, partnerskaber, landbrug, havene, ligestilling, uddannelse mm. Hvis ikke disse andre faktorer eller måldimensioner bliver inddraget i den politiske debat i Danmark, bevæger debatten sig i en skæv retning. Vi bliver nødt til at acceptere og inddrage den kompleksitet, der ligger i på samme tid at tale om og være optaget af alle 17 verdensmål. Regeringen bør gå forrest her og tale om verdensmålene som den overordnede dagsorden, som dernæst indeholder klimadagsordenen - og andre udfordringer.

Det hjælper ikke, at man i de politiske drøftelser om dette på forhånd erklærer, at stort set ingenting må ændres i såkaldt negativ retning. Fx: Væksten må ikke blive negativt påvirket, beskæftigelsen heller ikke, den økonomiske situation og udvikling må ikke påvirkes negativt osv. Det er klart, at hvis man på forhånd oplister så kortsigtede og specifikke krav, så er en transformation på forhånd udelukket. Vi ser det i den aktuelle danske politiske debat om klimalovgivningen, at nogle af partierne positionerer sig som tilhængere af en klimalovgivning, der ingen negative virkninger må have for borgere og virksomheder. Jeg tror, man kan sige meget enkelt og ligetil: Det kan ikke lade sig gøre. Det er umuligt at gennemføre de store samfundsmæssige ændringer, der er behov for og tale om her, uden at det af nogle vil opfattes og mærkes som noget negativt, som reduktion, som tilbagegang. Selvfølgelig vil det være sådan. Alligevel kan man på forsiden af et dagblad læse: Grøn omstilling bliver dyr og besværlig. (Børsen, den 24. februar 2020). Ja, hvad havde man ellers forestillet sig? Man kan sige én ting med sikkerhed: En fortsat ikke-grøn udvikling bliver endnu dyrere og endnu mere besværlig. Man kan ikke lave store ændringer uden store konsekvenser. 
Vi skal betragte verdensmålene, ikke som et problem eller en byrde for Danmark, erhvervslivet, fagforeningerne etc., men som en enestående mulighed. En mulighed for at udvikle et andet og bedre samfund, en mulighed for at være med i en global udvikling, bidrage til at udforme og virkeliggøre en global dagsorden. Levere - og modtage - viden, ydelser, rådgivning og produkter til en sådan national og global udvikling. Danmark som et verdensmålsland.

Jeg tilslutter mig Katherine Richardson, når hun (Politiken, den 26. januar 2020) siger: "Ingen data begrunder min optimisme, men alligevel tror jeg, at verden bliver et bedre sted”. Jeg synes i øvrigt, at der er holdepunkter for optimisme. Faktisk er bæredygtighed ved at blive en global dagsorden. Parlamenter, regeringer, virksomheder, fagforeninger, skoler, uddannelsesinstitutioner, civilsamfundsorganisationer - taler om og arbejder med bæredygtighed. Ikke, at det er ens overalt i verden. Thi det er det langt fra. Tværtimod er den måde, bæredygtighed kommer til udtryk og bliver italesat på, meget forskellig fra land til land, fra by til by etc. Men tendensen er klar. 


\section{Referencer}

De tanker, der er redegjort for i denne tekst, har jeg på forskellige måder redegjort for i andre sammenhænge. Jeg henviser bl.a. til følgende:

Bøger:

Steen Hildebrandt \& Per Fibæk Laursen: Når klokken ringer ud. Gyldendal Public. København 2009.

Steen Hildebrandt \& Michael Stubberup: Bæredygtig ledelse. Gyldendal. København 2010.

Steen Hildebrandt: Børnene er de vigtigste. Turbine. Århus 2012.

Steen Hildebrandt, Helle Jensen m.fl.: Empati. Det, der holder verden sammen. Rosinante. København 2012.

Steen Hildebrandt: Vækst og bæredygtighed. 2. Udgave. Libris. København 2015.

Steen Hildebrandt: Fremtiden er nu. Et essay om samfundets omstilling og nye muligheder. Systime. Aarhus 2015.

Steen Hildebrandt (red.): Bæredygtig global udvikling. Om FN’s 17 verdensmål i et dansk perspektiv. Jurist- og Økonomforbundets Forlag. København 2016.

Steen Hildebrandt: Astronautens blik. Klummer om vækst, vildveje og verdensmål. Jensen \& Dalgaard. København 2016.

Steen Hildebrandt: Verdensmålene - det vigtigste punkt på dagsordenen. KLS, Hvidovre 2018.

Steen Hildebrandt: Verdensmålene. Vor største mulighed og udfordring. Systime. Århus. 2. udgave 2018.

Steen Hildebrandt: Bæredygtighed: Need to have eller nice to have? Artikel i: Torben Bagge og Leo Jantzen (red): Skat med omtanke. Festskrift til Tommy V. Christiansen. Ex Toto Publishing. København 2019.

Steen Hildebrandt \& Lars Josephsen (red.): Globale mål. Visionen om bæredygtig udvikling. DJØF Forlag. København 2019.

Steen Hildebrandt: Danmark og verdensmålene. En ny dagsorden.

Nørhaven. Viborg. 3. udgave. Viborg 2020.

Steen Hildebrandt og Michael Stubberup: Social bæredygtighedskompetence og verdensmålene. Kapitel i: Daniela Cecchin \& Vicki Sieling (red.): Pædagogers Kompetencer i bevægelse. Akademisk Forlag. København 2020. 


\section{Artikler, kronikker og bidrag til bøger:}

Det er de 'bløde' kriterier, der skal redde verden. Mandag Morgen, den 11. december 2019.

Bæredygtig ledelse er den eneste vej frem. Tidsskrift for Dansk Sundhedsvæsen. 95. årgang, nr. 8, december 2019.

Det danske velfærdssamfund er ikke bæredygtigt. Mandag Morgen, nr. 40, den 2. december 2019.

Mål for verden og verdens udvikling. Kvan. Tidsskrift for læreruddannelse og skole, 39. årgang, nr. 115, december 2019.

Danmark som foregangsland. Ledelse i Dag 2018-2019. November 2019. Udgivet af Lederne.

Jo, verdensmålene må gerne styre universiteternes forskning. Sammen med Katherine Richardson. Mandag Morgen, den 11. september 2019.

Klimaet kræver lederskab, Mette. Mandag Morgen, den 13. juni 2019. Nordjyske Stiftstidende, den 14. juni 2019. Avisen Danmark, den 16. juni 2019.

Verdensmålene - man må tage stilling og beslutte. AAU - Matchmaking, nr. 2, 2019. Aalborg Universitet.

Verdensmålene - et dannelsestema. Steinerbladet, 2/2019.

Tænk, at Folketingets har en formand, der er så tosset. Politiken, den 30. maj 2019.

Skriv klodens fremtid ind i regeringsgrundlaget. Mandag Morgen, den 6. maj 2019.

En ny regering skal turde tale om verdensmålene. Avisen Danmark, den 11. maj 2019.

Danmark som foregangsland for bæredygtig ledelse. Lederne, 9. maj 2019.

Regnearksledelsen har fejlet. Mandag Morgen, den 8. april 2019. Som kronik: Avisen Danmark, den 18. april 2019 og Nordjyske Stiftstidende den 22. april 2019.

Verdensmålene. En vision for verden. Samfundslederskab i Skandinavien, vol. 34, nr. 1, 2019

Et lille skridt for Danmark - et kæmpe skridt for verdensmålene. Mandag Morgen, den 4. februar 2019.

Verdensmål. Kirken og religionerne bør gå foran for at forbedre planetens situation. Kristeligt Dagblad, den 10. januar 2019. 
Så er det heller ikke sværere med de verdensmål. Det store lederskab i den lille virksomhed. Mandag Morgen, den 14. januar 2019.

Fra best practice til next practice - organisations- og ledelsesforståelse i fremtiden Schultz Essens Magasinet, Nr. 1, Sommer 2019.

Jeg bliver holdt ansvarlig for min økonomiske bundlinje - ikke for verdensmålene. Steen Hildebrandt og Katherine Richardson. Mandag Morgen, nr. 7, den 25. februar 2019.

Vi må bygge velfærdssamfundet om efter verdensmålene. Avisen Danmark, den 30. december 2019.

Gør bæredygtig udvikling til rygraden i næste regeringsgrundlag Kronik. Medunderskriver. Morgenavisen Jyllands-Posten, den 19. april 2019.

Indkøbsordre fra fremtiden. Steen Hildebrandt og Katherine Richardson. Nordjyske Stiftstidende, den 11. marts 2019.

Vi har ikke kun brug for justeringer - tag religionerne til hjælp. Avisen Danmark, den 18. december 2018.

Ikke mere flyvsk snak om bæredygtighed. Avisen Danmark, den 15. januar 2019.

Alle danske virksomheder bør have blikket rettet mod FN's verdensmål. Steen Hildebrandt \& Flemming Besenbacher. JP Finans, den 6. marts 2019.

Everything is interconnected. Chapter in: Birgitte Kleis (red.): Co-creating Architecture. NORD Architects. 10. Grafisk Design \& Forlag. Copenhagen 2020.

Fremtiden kalder. Kapitel i: Elsebeth Jensen og Ole Løw (red.): Hvorfor går børn i skole? Akademisk Forlag. 2020.

Bæredygtig ledelse: En ny bæredygtig og global strategisk dagsorden. Kapitel i: Strategisk ledelse af mennesker. Håndbog for ledere. Psykologisk Forlag. 2020.

Den helt enkle tilgang til verdensmålene. Mandag Morgen, den 26. februar 2020.

Fremtidens velfærdssamfund skal være bæredygtigt. Netavisen Pio, den 26. februar 2020.

Klimaet er vigtigt, men verdensmålene er det overordnede. Altinget, den 17. januar 2020. Du er en del af helheden - så tag ansvar for den. Mandag Morgen, nr. 3, den 20. januar 2020.

Det bæredygtige velfærdssamfund er vores næste mål. Altinget, den 13. januar 2020. Elektronisk version og Altinget Magasin, nr. 33, februar 2020. 
Økologi baner vejen for FN's verdensmål. Steen Hildebrandt, Lars-Christian Brask og Preben M. Lauridsen Politiken, den 16. januar 2020. 